\title{
Removal of Zinc by Nano-scale Zero Valent Iron in Groundwater
}

\author{
Nik Nurul Ilani Nik Redzauddin ${ }^{1, a}$, Jalina Kassim ${ }^{2, b}$ and Amnorzahira Amir ${ }^{3, c}$ \\ ${ }^{1,2,3}$ Faculty of Civil Engineering, Universiti Teknologi MARA, 40450 Shah Alam, Selangor, \\ Malaysia. \\ 1,2,3 Institute of Infrastructure Engineering and Sustainability Management (IIESM), Universiti \\ Teknologi MARA, 40450 Shah Alam, Selangor, Malaysia.
}

ailaniredzauddin@yahoo.com, bjalina@salam.uitm.edu.my, camnorzahira@salam.uitm.edu.my

Keywords: Zinc, nZVI, groundwater, removal kinetic rate

\begin{abstract}
Groundwater has long been identified as potential alternative of clean water supply due to its reliable quantity. However, pollution of groundwater due to anthropogenic factor still remains a challenging issue. To date, nano-scale zero valent iron (nZVI) has received great attention for its capability to treat various contaminants including chlorinated organics and metals. This study investigate Zinc $(\mathrm{Zn})$ removal in aqueous solution by nano-scale zerovalent iron (nZVI). The characteristics study of the synthesized nZVI particles were investigated by its particle size and surface morphology using Scanning Electron Microscope (SEM) and Transmission Electron Microscope (TEM). SEM and TEM analyses verified that the particles size of synthesized nZVI were $71 \mathrm{~nm}(<100 \mathrm{~nm})$. Structure of nZVI congragate to each other and a thin layer of oxide layer formed on the outer part of the nZVI particle. In the batch study, removal kinetic of $\mathrm{Zn}$ increased from 0.14 to $0.18 \mathrm{mins}^{-1}$ as the concentration of $\mathrm{Zn}$ increased from 0.1 to $0.5 \mathrm{ppm}$. However, the removal kinetic decreased from 0.162 to $0.148 \mathrm{mins}^{-1}$ as the amount of nZVI was increased from $0.25 \mathrm{mg} / \mathrm{L}$ to $2.50 \mathrm{mg} / \mathrm{L}$. At $\mathrm{pH} 7$, removal kinetic reached $0.157 \mathrm{mins}^{-1}$. However as the $\mathrm{pH}$ suspension decreases to $\mathrm{pH} 6.5$, the removal kinetics decreased significantly to $0.144 \mathrm{mins}^{-1}$. The same behaviour was observed at $\mathrm{pH} 9$ where the removal kinetics was decreased to $0.117 \mathrm{mins}^{-1}$. Removal kinetic of $\mathrm{Zn}$ significantly decreased at basic condition due to the formation of passivation layer which decreased the density of reactive surface area (e.g., $\mathrm{Fe}^{0}$ and $\mathrm{Fe}^{2+}$ ) on the surface of nZVI. Experimental results from this study can provide basic knowledge of effectiveness of $\mathrm{Zn}$ removal mechanisms by $\mathrm{nZVI}$ at different environment conditions and provide potential remediation technology for the treatment of toxic heavy metals in groundwater.
\end{abstract}

\section{Introduction}

Industrial, agricultural, mining and waste disposal are the anthropogenic activities have the potential to leach heavy metals (e.g., cadmium, lead and zinc) into groundwater [1]. Heavy metals are toxic contaminants and can give serious effect to biodiversity and human health. The close relation between the soil and corresponding groundwater contamination causes the toxic metals in the contaminated soils to seep through the fissured and faulted zones, leading to groundwater pollution [1]. There is an increased concern in Malaysia regarding the environmental impacts of groundwater contamination by the bioavailability and leaching of toxic heavy metals in soil and groundwater. The government takes serious efforts to remediate the contaminated groundwater to achieve cleaner soil and potable groundwater.

Zinc $(\mathrm{Zn})$ is one of heavy metals that is naturally available in the environment. The concentration of $\mathrm{Zn}$ in uncontaminated water is in a range of $10^{-10}$ to $10^{-6} \mathrm{M}$ [2]. However human activities such as mining or steel production activities cause serious $\mathrm{Zn}$ contamination to surface and groundwater. Excessive amount of $\mathrm{Zn}$ uptake may cause human deficiencies such as dermatitis, diarrhea, alopecia, mental disturbance and intercurrent infections [3]. Therefore efforts on elucidating $\mathrm{Zn}$ contamination and its remediation initiatives in groundwater should be given serious attention.

Remediation technologies of contaminated groundwater have emerge on utilizing nanoscale zero valent iron (nZVI) in the removal of heavy metals such as $\mathrm{Cd}, \mathrm{Ni}, \mathrm{Zn}$, As and $\mathrm{Cr}[4,5.6]$. nZVI 
offers an advantage to groundwater remediation due to its unique properties of high surface reactivity and enormous reactive surface area [7]. Due to its nano size, nZVI application can be relatively easy to transport and inject effectively into contaminated groundwater. With its high reactive surface area, nZVI provide high potential contaminant removal and degradation through reduction and adsorption [8].

\section{Materials and Methods}

List of Chemicals. Chemical utilized for this study include, sodium borohydride $\left(\mathrm{NaBH}_{4}\right)(99 \%$, Aldrich), iron chloride $\left(\mathrm{FeCL}_{3}\right)(98 \%$, Aldrich), acetone (99\%, Merck) for nZVI synthesis, MOPs, $\mathrm{p} K_{\mathrm{a}}=7.2$ for $\mathrm{pH} 6.5$ to 7.9 and hydrochloric acid (HCL) $(0.1 \mathrm{M}$, Merck) for preparing buffer solution. Standard stock solution of Zn, (1000 ppm, Merck), Zinco Ver 5 reagent powder pillow and cyclohexanone was utilized for Zn determination. Deaerated deionized water (DDW) was prepared using ultra pure water $(18 \Omega . \mathrm{cm})$ purged by $\mathrm{N}_{2}$. Anaerobic chamber was maintained purged with $95 \% \mathrm{~N}_{2}$ and $5 \% \mathrm{H}_{2}$. All reagents and solutions used in the experiments was prepares using DDW.

Synthesize of nZVI. Synthesis of nZVI were performed by using sodium borohydride $\left(\mathrm{NaBH}_{4}\right)$ $(0.9 \mathrm{mM}, 1000 \mathrm{~mL})$ and iron chloride $\left(\mathrm{FeCl}_{3}\right)(0.11 \mathrm{mM}, 1000 \mathrm{~mL})$, followed the method proposed by Wang and Zhang [9]. The $\mathrm{NaBH}_{4}$ functions as a reducing agent in order to reduce $\mathrm{FeCl}_{3}$ to produce nZVI. Both chemicals were mixed by dropping $\mathrm{NaBH}_{4}$ solution into $\mathrm{FeCl}_{3}$ solution continuously while stirring the mixture well. Fe (III) will be reduced to $\mathrm{Fe}(0)$ by hydrogen generated during the reaction. Black iron particles was formed and separated from the solution by centrifuge at $3000 \mathrm{rpm}$ at $10 \mathrm{~min}$. The nZVI were washed twice with DDW and once with ethanol before dried and stored in an aerobic chamber.

Batch Experiments. Batch experiments were conducted to determine removal kinetic of $\mathrm{Zn}$ by nZVI. To investigate the effectiveness of Zn removal by nZVI, experiments were conducted in 40 $\mathrm{mL}$ amber glass vials sealed with three layered septum system. The three layered septum consist of rubber septum, aluminum foil and parafilm. MOPS buffer solution $(50 \mathrm{mM})$ was prepared using MOPS sodium salt and DDW. $\mathrm{pH}$ of buffer solution was adjusted from $\mathrm{pH} 9$ to $\mathrm{pH} 7$ using $0.1 \mathrm{M}$ HCL acid. Exact amount of nZVI 0.05g was weighted and transferred to each vials and MOPS buffer solution $(50 \mathrm{mM})$ was poured into each vials without headspace to keep the $\mathrm{pH}$ suspension constant at 7 . $\mathrm{Zn}$ with concentration of $0.30 \mathrm{ppm}$ was then introduced into each vial and to initiate reaction between $\mathrm{nZVI}$ and $\mathrm{Zn}$. Vials were then rapidly capped, mounted on a tumble mixer, and rotated at $7 \mathrm{rpm}$ at room temperature $\left(25 \pm 0.5^{\circ} \mathrm{C}\right)$ for 30 minutes. All the experimental works were conducted in an anaerobic chamber. Samples and controls were prepared in duplicate. The removal of $\mathrm{Zn}$ was determined by measuring aqueous concentration of $\mathrm{Zn}$ in the $\mathrm{nZVI}$ suspension at each sampling time. At sampling time of every 10 minutes, samples were taken out of the anaerobic chamber, centrifuged for $5 \mathrm{~min}$ at $5000 \mathrm{rpm}$, and then aliquots of aqueous solution were collected to measure the $\mathrm{Zn}$ concentration. Concentration of $\mathrm{Zn}$ was determined by HACH Spectrometer DR5000, Method 8009. Batch kinetic experiments were conducted to investigate effect of concentrations of $\mathrm{Zn}$ and $\mathrm{nZVI}$, and $\mathrm{pH}$ on the removal of $\mathrm{Zn}$ by $\mathrm{nZVI}$. Three different concentrations of $\mathrm{Zn}(0.1 \mathrm{ppm}, 0.3 \mathrm{ppm}$ and $0.5 \mathrm{ppm})$ were prepared by diluting $\mathrm{Zn}$ standard stock solution (1000 ppm, Merck) in DDW. Initial concentration of nZVI was set at $1 \mathrm{mg} / \mathrm{L}$ at $\mathrm{pH} 7$. Samples were prepared by following the same way as the batch test described above. To investigate effect of nZVI on the removal of Zn by nZVI at $\mathrm{pH} 7$, three different concentrations of nZVI $(0.01 \mathrm{~g}, 0.05 \mathrm{~g}$ and $0.10 \mathrm{~g})$ were weighted and transferred into vials. Initial concentration of $\mathrm{Zn}$ was set at $0.3 \mathrm{ppm}$ at $\mathrm{pH}$ 7. To study effect of $\mathrm{pH}$ on the removal $\mathrm{Zn}$ by $\mathrm{nZVI}, 50 \mathrm{mM}$ MOPS buffer and 0.1 M HCL were used to adjust and keep the $\mathrm{pH}$ values constant at 6.5, 7 and 9. Initial $\mathrm{Zn}$ and nZVI concentrations were set at $0.3 \mathrm{ppm}$ and $1 \mathrm{mg} / \mathrm{L}$, respectively. Samples were prepared by following the same way as the batch test described above. 


\section{Analytical procedures}

Characterization of nZVI. The characteristics study of the synthesized nZVI particles were investigated by its particle size and surface morphology using Scanning Electron Microscope (SEM) and Transmission Electron Microscope (TEM). nZVI sample were dried in anaerobic condition for 24 hours. It was carefully packed under anaerobic condition to avoid its surface oxidation prior to analysis.

Zinc Concentration. Concentration of $\mathrm{Zn}$ was determined using HACH Spectrometer DR5000, following Method 8009. Aliquots of aqueous solution collected from samples and controls were transferred to $20 \mathrm{ml}$ mixing cylinder and Zinco Ver 5 Reagent Powder Pillow and cyclohexanone were added for Zn determination.

\section{Result and Discussion}

Characterization Study of nZVI. Fig. 1 shows the particle size and morphology of synthesized nZVI using SEM. The resulting image of nZVI shows that the size of nZVI was approximately $71 \mathrm{~nm}$ and it was aggregated to each other due the strong dipole-dipole magnetic of individual particles [4]. Size of nZVI was also measured using TEM (Fig. 1 (b) and (c)). Fig. 1(b) and (c) show that size of synthesized nZVI was $20 \mathrm{~nm}$ and $60 \mathrm{~nm}$, respectively. These results strongly confirmed that synthesized nZVI in this study was in nano-scales $(<100 \mathrm{~nm})$. This experimental result is consistent with the previous study reported by Efecan [10].

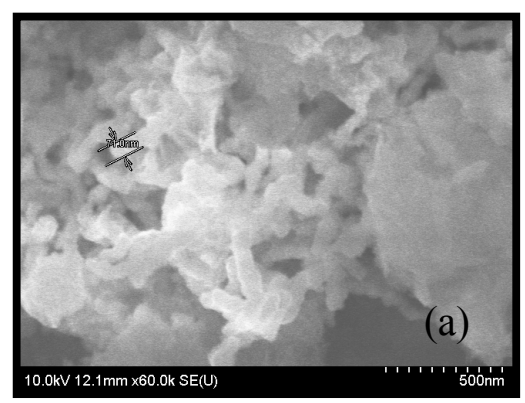

Fig 1(a): SEM image of nZVI

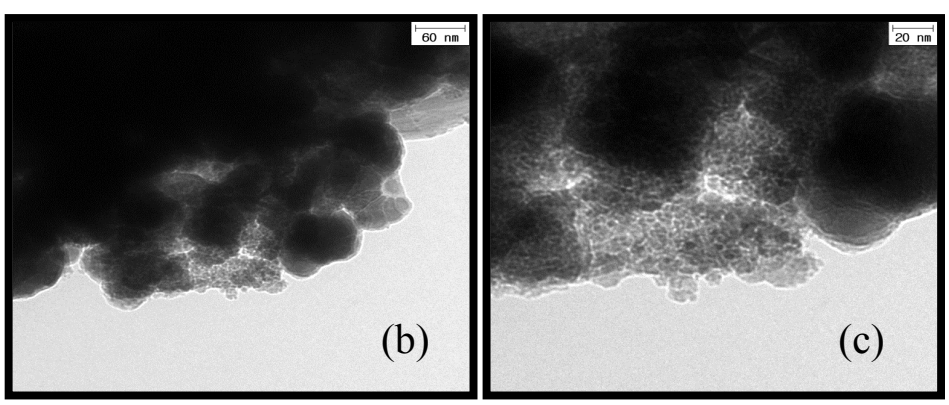

Figure 1 (b) and (c): TEM image of nZVI

Removal of Zn by nZVI. Fig. 2 shows the removal of $\mathrm{Zn}$ by nZVI at $\mathrm{pH} 7$. Based on the result obtained, the removal of $\mathrm{Zn}$ is observed immediately at the first 10 minutes of reaction time. At 20 minutes reaction time, $\mathrm{Zn}$ was completely removed. The removal kinetic of $\mathrm{Zn}$ removal by $\mathrm{nZVI}$ at $\mathrm{pH} 7$ was $0.157 \mathrm{mins}^{-1}$. This experimental result indicates that $\mathrm{nZVI}$ is capable to remove $\mathrm{Zn}$ at natural $\mathrm{pH}$. Result suggests that redox reaction between $\mathrm{nZVI}$ and $\mathrm{Zn}$ probably occur around $\mathrm{pH} 7$. Similar observation was reported by Khatoon et al [11].

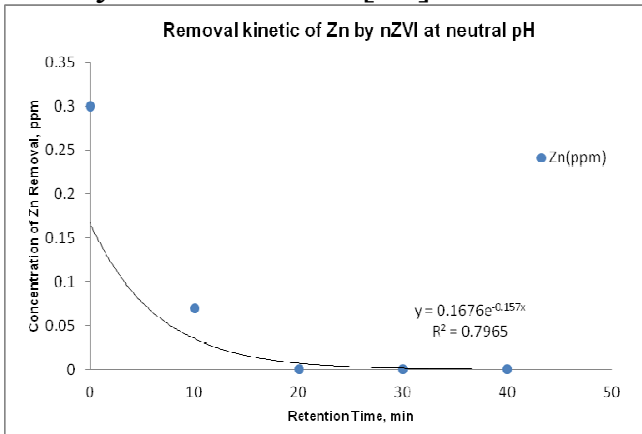

Figure 2. Removal of Zn by nZVI. (Initial condition $\mathrm{nZVI}=0.05 \mathrm{~g} ; \mathrm{Zn}=0.30 \mathrm{ppm} ; \mathrm{pH} 7$ ).

Effect of Zinc Concentration on Removal of Zinc by nZVI. Fig. 3(a) and (b) show removal kinetic of $\mathrm{Zn}$ at different concentration of $\mathrm{Zn}(0.1 \mathrm{ppm}, 0.3 \mathrm{ppm}$ and $0.5 \mathrm{ppm})$ at $\mathrm{pH} 7$. It was observed that at concentration of $0.1 \mathrm{ppm}, 90 \%$ of $\mathrm{Zn}$ concentration was removed at the first 10 minutes and totally removed on the following sampling time. At $0.3 \mathrm{ppm} \mathrm{Zn}$ concentration, $\mathrm{Zn}$ was completely removed at 20 minutes followed by concentration of $\mathrm{Zn}$ at $0.5 \mathrm{ppm}$ which was 
completely removed at 30 minutes reaction time. This result shows that higher $\mathrm{Zn}$ concentration requires longer reaction time to be entirely removed. Similar behavior of Zn removal by nZVI was observed in previous studies where contact time significantly influence the percent removal of $\mathrm{Zn}$ $[11,12,13]$. The removal kinetic rate of $\mathrm{Zn}$ at $0.5 \mathrm{ppm}$ of $\mathrm{Zn}$ concentration was $0.18 \mathrm{mins}^{-1}$, which is 1.15 time greater than removal kinetic rate of $\mathrm{Zn}$ at $0.3 \mathrm{ppm}$ of $\mathrm{Zn}$ concentration $\left(\mathrm{k}=0.157 \mathrm{mins}^{-1}\right)$. While the removal kinetic rate of $\mathrm{Zn}$ at $0.1 \mathrm{ppm}$ of $\mathrm{Zn}$ concentration $\left(\mathrm{k}=0.115 \mathrm{mins}^{-1}\right)$ was 1.06 time lower than the removal kinetic rate of $\mathrm{Zn}$ at $0.3 \mathrm{ppm}$ of $\mathrm{Zn}$ concentration. Removal kinetic rate of $\mathrm{Zn}$ was significantly increased as concentration of $\mathrm{Zn}$ increased from $0.1 \mathrm{ppm}$ to $0.5 \mathrm{ppm}$. These experimental results indicate that removal kinetic rate of $\mathrm{Zn}$ by nZVI was significantly controlled by concentration of $\mathrm{Zn}$ in this system. Results suggest that $0.05 \mathrm{~g}$ of $\mathrm{nZVI}$ provides sufficient reactive surface to completely remove 0.1 to $0.5 \mathrm{ppm}$ of $\mathrm{Zn}$ at $\mathrm{pH} 7$ in this study. The results from this study are consistent with the experimental results reported by Khatoon et al [11].

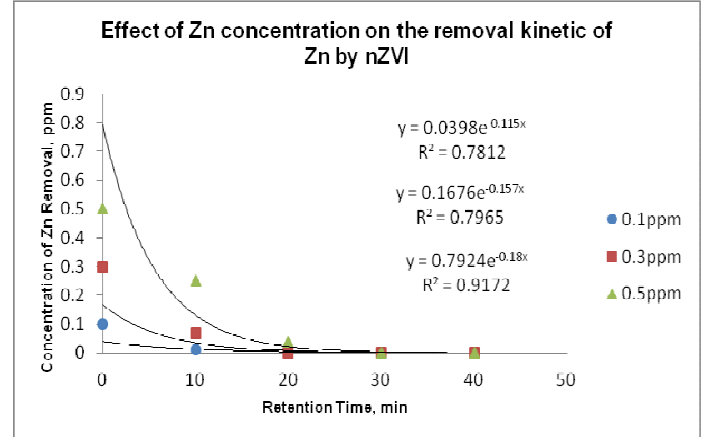

Figure 3(a): Effect of $\mathrm{Zn}$ concentration on the removal kinetic of $\mathrm{Zn}$ by $\mathrm{nZVI}$ at $\mathrm{pH} 7$.

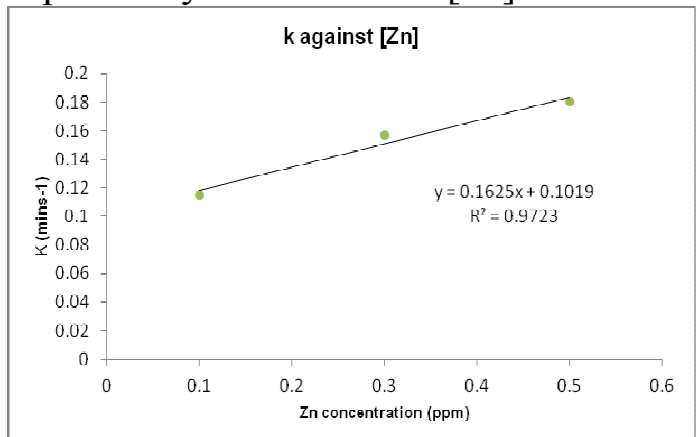

Figure 3(b): Removal kinetic rate value $(\mathrm{k})$ of $\mathrm{Zn}$ by $\mathrm{nZVI}$ at different concentration of $\mathrm{Zn}(\mathrm{pH} 7,[\mathrm{nZVI}]=$ $0.001 \mathrm{~g} / \mathrm{L})$

Effects of nZVI Concentration on Removal of Zn by nZVI. Fig. 4 (a) shows removal kinetic of $\mathrm{Zn}$ by $\mathrm{nZVI}$ at different concentration of nZVI at neutral $\mathrm{pH}$. Zn was completely removed by different concentrations of nZVI $(0.01 \mathrm{~g}, 0.05 \mathrm{~g}$ and $0.10 \mathrm{~g})$ in $30 \mathrm{mins}$. This result indicates that even at low concentration of nZVI $0.25 \mathrm{mg} / \mathrm{L}(0.01 \mathrm{~g})$ was sufficient to remove $0.3 \mathrm{ppm}$ of $\mathrm{Zn}$ at neutral $\mathrm{pH}$. However, result presented contradicts with results reported by Liang et al. and Kržišnik et al.where efficiency of $\mathrm{Zn}$ removal significantly increased with the increased of nZVI loading [12,13]. Fig. 4 (b) illustrates removal kinetic rate of Zn by nZVI at different concentration of nZVI. Removal kinetic rate of $\mathrm{Zn}$ was significantly decreased as concentration of $\mathrm{nZVI}$ increased from $0.25 \mathrm{mg} / \mathrm{L}, 1.25 \mathrm{mg} / \mathrm{L}$ and $2.50 \mathrm{mg} / \mathrm{L}$. The removal kinetic rate of $\mathrm{Zn}$ with $0.25 \mathrm{mg} / \mathrm{L}$ of nZVI was $0.162 \mathrm{mins}^{-1}$, which is 1.03 time greater than removal kinetic rate of $\mathrm{Zn}$ at $1.25 \mathrm{mg} / \mathrm{L}$ of nZVI $(\mathrm{k}=$ $\left.0.157 \mathrm{mins}^{-1}\right)$. While the removal kinetic rate of $\mathrm{Zn}$ at $2.50 \mathrm{mg} / \mathrm{L}$ of $\mathrm{nZVI}\left(\mathrm{k}=0.148 \mathrm{mins}^{-1}\right)$ was 1.06 time lower than removal kinetic rate of $\mathrm{Zn}$ at $1.25 \mathrm{mg} / \mathrm{L}$ of $\mathrm{nZVI}$. This result indicates that removal kinetic rate of $\mathrm{Zn}$ was not dependent on the concentration of nZVI in this system. This was probably occurred due to the agglomeration of nZVI particles itself at high concentration of nZVI. Literatures have reported that agglomeration of nZVI may decrease reactive surface area on the nZVI surface. Due to this reason, electron transfer from the reactive surface of nZVI to Zn was inhibited and $\mathrm{Zn}^{2+}$ could not be reduced to $\mathrm{Zn}[14,15]$. The results from this study is consistent with the experimental results reported in the previous study $[12,13]$.

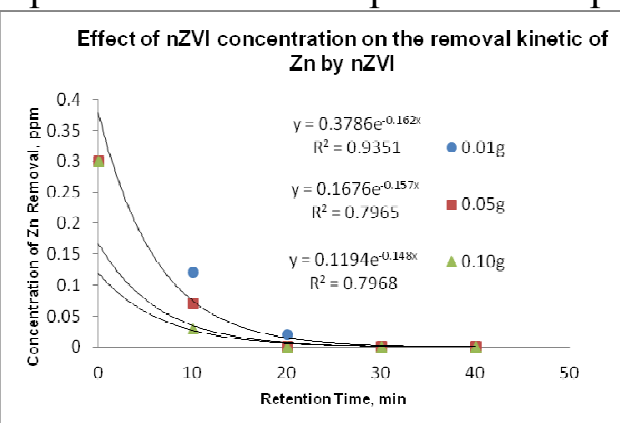

Figure 4(a): Graph effect of nZVI concentration on the removal kinetic of $\mathrm{Zn}$ by $\mathrm{nZVI}$

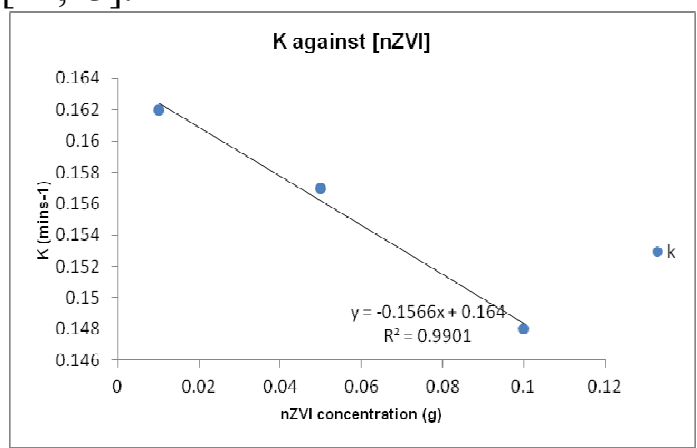

Figure 4(b): Removal kinetic rate value $(\mathrm{k})$ of $\mathrm{Zn}$ by $\mathrm{nZVI}$ at different concentration of $\mathrm{nZVI}(\mathrm{pH} 7,[\mathrm{Zn}]=0.3 \mathrm{ppm})$ 
Effects of pH on Zn removal by nZVI. Fig. 5 (a) shows removal kinetic of Zn by nZVI at different $\mathrm{pH}$. Zn was completely removed by nZVI at $\mathrm{pH}$ 6.5,7 and 9 in 40 mins. There was not significant different of the removal of $\mathrm{Zn}$ by $\mathrm{nZVI}$ at $\mathrm{pH} 6.5$ and 7 . However, removal of $\mathrm{Zn}$ by nZVI was slower at $\mathrm{pH} 9$ than that at $\mathrm{pH} 6.5$ and 7. This result indicates that removal of $\mathrm{Zn}$ by nZVI was significantly influenced by $\mathrm{pH}$ condition in this system. Similar result was observed by Kržišnik et al where highest $\mathrm{Zn}$ removal was obtained at $\mathrm{pH} 7$ [13]. In neutral $\mathrm{pH}$ range, strong magnetic forces enhanced the particles aggregation, thus increasing the potential of contaminant removal efficiency $[13,16]$. Fig. 5 (b) illustrates removal kinetic rate of $\mathrm{Zn}$ by $\mathrm{nZVI}$ at different $\mathrm{pH}$. Removal kinetic rate of $\mathrm{Zn}$ was significantly decreased as $\mathrm{pH}$ increased from neutral to alkaline conditions. However, the removal kinetic of Zn by nZVI was slightly increased at $\mathrm{pH} 7$.

The removal kinetic rate of $\mathrm{Zn}$ at $\mathrm{pH} 7$ was $0.157 \mathrm{mins}^{-1}$, which is 1.3 time greater than removal kinetic of $\mathrm{Zn}$ at $\mathrm{pH} 9\left(\mathrm{k}=0.117 \mathrm{mins}^{-1}\right)$. While the removal kinetic rate of $\mathrm{Zn}$ at $\mathrm{pH} 6.5(\mathrm{k}=0.144$ mins $^{-1}$ ) was 1.1 time lower than at $\mathrm{pH} 7$. This results indicate that fast removal kinetic of nZVI occurred at $\mathrm{pH} \mathrm{7,} \mathrm{suggesting} \mathrm{that} \mathrm{nZVI} \mathrm{particles} \mathrm{may} \mathrm{have} \mathrm{high} \mathrm{density} \mathrm{of} \mathrm{reactive} \mathrm{surface} \mathrm{on} \mathrm{its}$ surface at this condition. This result is consistent with the study reported by Efecan [10]. Literatures have reported that formation of passivation layer on the surface of $\mathrm{nZVI}$ at high $\mathrm{pH}$ condition probably decrease the removal efficiency of Zn by nZVI $[11,12]$. The formation of passivation layer decreases the density of reactive surface area (e.g., $\mathrm{Fe}^{0}$ and $\mathrm{Fe}^{2+}$ ) on the surface of nZVI [11]. While, the kinetic removal was slightly increased at $\mathrm{pH} 7$ probably because the density of reactive surface area was sufficient to enhance removal of $\mathrm{Zn}$ by $\mathrm{nZVI}[11,12]$. This result suggests that $\mathrm{pH}$ value is an important factor to be considered during the reduction process between Zn and nZVI. The results from this study is consistent with the experimental results reported in the previous study $[12,13]$.

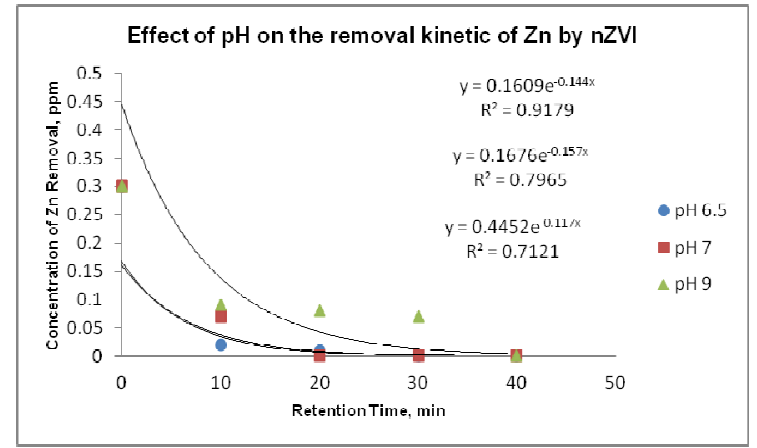

Figure 5(a): Graph effect of $\mathrm{pH}$ on the removal kinetic of $\mathrm{Zn}$ by nZVI

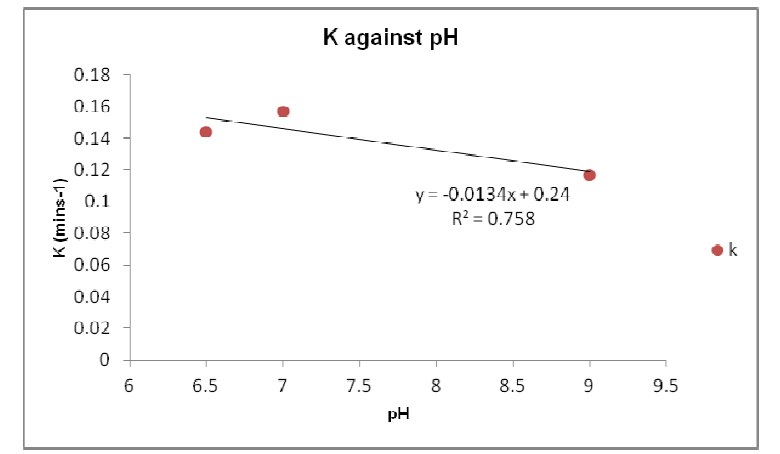

Figure 5(b): Removal kinetic rate value $(\mathrm{k})$ of $\mathrm{Zn}$ by $\mathrm{nZVI}$ at different $\mathrm{pH} \quad([\mathrm{nZVI}]=0.001 \mathrm{~g} / \mathrm{L},[\mathrm{Zn}]=0.3 \mathrm{ppm})$

\section{Conclusion}

Results from this study shown significant finding on the removal of $\mathrm{Zn}$ by $\mathrm{nZVI}$ in an anaerobic condition. The optimum condition for removal of $\mathrm{Zn}$ by nZVI was identified in this study ([Zn] : $0.3 \mathrm{ppm},[\mathrm{nZVI}]: 0.25 \mathrm{mg} / \mathrm{L}, \mathrm{pH} 7$ ). Finding from this study provides significant fundamental knowledge on the characteristic of removal of Zn by nZVI at different environment conditions. Thus, this finding can be proposed as a potential remediation method to remove $\mathrm{Zn}$ in groundwater. This study is very significant to Department of Environmental Malaysia because finding from this study could be implemented to achieve sustainable development in remediation technology of groundwater in Malaysia.

\section{Acknowledgment}

Grateful acknowledgement is address to UiTM, Research Intensive Faculty Grant (600-RMI/DANA 5/3/RIF (740/2012)) for the research funding. 


\section{References}

[1] Y. Liang, X. Cao, L. Zhao \& E. Arellano. (2014). Biochar- and Phosphate-Induced Immobilization of Heavy Metals in Contaminated Soil and Water: Implication on Simultaneous Remediation of Contaminated Soil and Groundwater, Environment Science Pollution Res 21, pp. 4665-4674.

[2] T. Cheng, \& H. E. Allen. (2006). Comparison of Zinc Complexation Properties of Dissolved Natural Organic Matter from Different Surface Waters, Journal of Environmental Management 80, pp. 222-229.

[3] C.T. Walsh, H. H. Sandstead, A.S. Prasad, P. M. Newberne \& P.J. Fraker. (1994). Zinc: health effects and research priorities for the 1990s. Environ Health Perspect. 102, pp. 5-46.

[4] R. Singh, V. Misra, \& R. P. Singh. (2012). Removal of hexavalent chromium from contaminated ground water using zero-valent iron nanoparticles. Environmental Monitoring Assessment, 184, 3643-3651.

[5] H. Zhu, Y. Jia, \& H. Wang. (2009). Removal of arsenic from water by supported nano zerovalent iron on activated carbon. Journal of Hazardous Material, 172, 1591-1596.

[6] J. Dries, L. Bastiaens, D. Springael, S. N. Agathos, \& L, Diels. (2005). Combined removal of chlorinated ethened and heavy metals by zerovalent iron in batch and continuous flow column system. Environmental Science \& Technology, 39, 8460-8465.

[7] R. Yuvakkumar, V. Elango, V. Rajendran \& N. Kannan. (2011) Preparation and characterization of zero valent iron nanoparticle. Digest Journal of Nanomaterials and Biostructures, 6(4), 1771-1776.

[8] J. E. Martin, A. A. Herzing, W. Yan, X. Q. Li, B. E. Koel \& C. J. Kiely. (2008). Determintation of the oxide layer thickness in core shell zero valent iron nanoparticles. Langmuir, 24, 4329-4334.

[9] C. B. Wang \& W. X. Zhang. (1997). Synthesizing Nanoscale Iron Particles for Rapid and Complete Dechlorination of TCE and PCBs, Environmental Science \& Technology 31, No. 7.

[10] N. Efecan. (2008). Characterization of The Adsorption Behaviour of Aqueous Cd(Ii) and $\mathrm{Ni}$ (Ii) Ions on Nanoparticles of Zero-Valent Iron, Izmir Institute of Technology.

[11] N. Khatoon, A. H. Khan, V. Pathak, N. Agnihotri \& M. Rehman. (2013). Removal Of Hexavalent Chromium from Synthetic Waste Water using Synthetic Nano Zero Valent Iron (nZVI) as Adsorbent, International Journal of Innovative Research in Science, Engineering and Technology 2(11), pp. 6140-6149.

[12] W. Liang, C. Dai, X. Zhou, \& Y. Zhang. (2014). Application of Zero-Valent Iron Nanoparticles for the Removal of Aqueous Zinc Ions under Various Experimental Conditions. PLoS ONE 9(1), e85686.

[13] N. Kržišnik, A. Mladenovič, A. A. Škapin, L. Škrlep, J. Ščančar \& R. Milačič. (2014). Nanoscale zero-valent iron for the removal of $\mathrm{Zn}^{2+}$, $\mathrm{Zn}$ (II)-EDTA and $\mathrm{Zn}$ (II)-citrate from aqueous solutions. Journal of Science of the Total Environment 476-477, pp 20-28.

[14] U.S. Environmental Protection Agency, (2007). Nanotechnology White Paper, Science Policy Council.

[15] P. G. Tratnyek \& R. L. Johnson. (2006). Nanotechnologies for environmental cleanup, Nanotoday.

[16] J. Fatisson, S. Ghoshal \& N. Tufenkji. (2010). Deposition of Carboxymethylcellulose-Coated Zero-Valent. Langmuir 26(15), pp 12832-12840. 